\title{
Effect of Self-Management Guidelines on Health Outcomes for Patients with Systemic Lupus Erythematosus
}

\author{
Prof. Dr. Labiba Abd Elkader Mohammed ${ }^{1}$, Prof. Dr. Abd Elrazek Abd Ellatef \\ Maaty $^{2}$, Ass. Prof. Dr. Eman Saleh Shahin ${ }^{3}$, Ass. Prof. Dr. Amal Baker Abo El-ata \\ ${ }^{4}$,and Shaymaa Elsayed Mosaad Mohammed ${ }^{5}$. \\ ${ }^{1}$ Prof of Adult Nursing, Cairo University; ${ }^{2}$ Prof of General Medical and Cardiology- \\ Faculty of Medicine, Mansoura University; ${ }^{3}$ Assistant Professor of Medical - Surgical \\ Nursing, Faculty of Nursing - Port Said University; ${ }^{4}$ Assistant Professor of Medical - \\ Surgical Nursing, Faculty of Nursing - Port Said University; ${ }^{5}$ Clinical Instructor, \\ Mansoura University, Egypt.
}

\begin{abstract}
Background: Systemic lupus erythematosus (SLE) is an autoimmune, rheumatic disease, potentially affecting most organ systems. The disease is commonly considered to be chronic and occurs in often unpredictable flares, with alternating low and high disease activity. Good self-management is essential to managing lupus; as individuals with SLE can improve their prognosis by learning about many aspects of the illness as well as closely monitoring their own health with their care providers. Aim of the study: This study aims to evaluate the effect of Self-Management Guidelines on Awareness, health outcome and Self-Efficacy for Patients with Systemic Lupus Erythematosus in Mansoura University Hospital. Study design: A quasiexperimental design was utilized to accomplish the aim of this study. Setting: The study was conducted at the medical department inpatients and medical clinics outpatients at Mansoura University Hospital. Subject: A convenient sample of all available patients admitted to the medical department inpatients and medical clinics outpatients at Mansoura University Hospital within 6 months which reached to 65 patients from September 2015 to February 2016. Tool of data collection: Health assessment Questionnaire, Health Outcomes Questionnaire consists of fatigue severity scale \&pain severity scale. Results: there were high statistically significant difference regarding severe pain, generalized health status and level of awareness $(\mathrm{P}<0.001)$ post implementation of self-management guidelines. The study concluded that: The systemic Lupus Erythematosus self-management guidelines had positive effects on the patients in reducing disability, fatigue, pain, improving. The study recommended that: Further researches about self-management of patients with SLE are highly recommended to reach the peak level of health satisfaction among those patients
\end{abstract}

Keywords: SLE, Self-management guidelines, Disability, fatigue, Pain, management. 


\section{INTRODUCTION}

Systemic lupus erythematosus (SLE) is a potentially life-threatening autoimmune rheumatic disease, which can affect most organ systems. The disease, considered mostly as a chronic condition, occurs in often unpredictable flares, with periods of high disease activity followed by periods of lower disease activity. Symptoms of the disease vary widely in severity and depend on which organ is affected by inflammation. The skin is a common site for inflammation, as well as the musculoskeletal system. Nephritis indicates disease activity in the kidney and is a serious condition. Also, neurological symptoms such as seizure and psychosis may occur and indicate that the brain is affected. (Rahman \& Isenberg, 2012).

In Egypt; we have no valid statistics about prevalence and incidence of SLE among populations. Worldwide Prevalence of SLE ranges from 28.3-149.5./100000 per year. On other hand; at least seven million people worldwide have a form of lupus and most people will developed lupus between the ages of 15 - 44 (The Lupus Foundation of America, 2011).

Self-management is essential to managing lupus. Self-management is what the patient with SLE does to better manage their conditions. Also it describes the strategies that individuals use to manage the disease process itself, any emotional impacts of living with the condition, and the changes that occur to everyday living as a result of the condition. This involves finding information, making decisions and taking action (Zhang, Hochberg, Perlmutter, Tan, Cohen\& Medsger, 2011).

Fatigue of lupus can't be ignored. It's much more than just feeling tired. It can make getting out of bed every morning seem like climbing a mountain. Ordinary tasks, like cooking dinner or doing the laundry, can seem impossible. Fatigue is a symptom that others can't see, which means they may not understand how bad patient feels. Even worse, patient may feel like no matter how much get rest, the fatigue will never go away. (Long, 2013).

Pain in SLE is described as a common and burdensome symptom that may affect several dimensions in human's life, such as impaired quality of life, increased fatigue, anxiety and depression. This means that pain, when present, may constitute a great symptom burden for patients with SLE. Despite advancement in medical care 
and treatment of SLE, reports exist where patients with the disease express dissatisfaction with how pain is met by the healthcare service. Feelings of not being understood may create indignity and suffering (Pettersson et al., 2012).

\section{Significance of the study:-}

Systemic Lupus Erythematosus is a multi-system disease which affects the life style of the patients with a huge number of complications which affects all the body system. . Recent studies showed that increased number of patients with Systemic Lupus Erythematosus and important of participate in self-help or self-management course to decreased reports of pain, increased functional abilities and a reduced number of hospitalizations and physician visits. Self-management and patient empowerment enable patients to make informed choice about their life (David, 2011). The systemic lupus erythematosus self-management guidelines had positive effect on the patients' health outcomes regarding fatigue and pain, improving knowledge, coping skills and self-efficacy.

\section{AIM OF STUDY:}

This study aims to:

Evaluate the effect of Self-Management Guidelines on Awareness, health outcome and Self-Efficacy for Patients with Systemic Lupus Erythematosus in Mansoura University Hospital.

\section{Objectives:}

1. Assess the health status of patients with Systemic Lupus Erythematosus.

2. Plan self-management guidelines for patients with Systemic Lupus Erythematosus.

3. Implement self-management guidelines for patients with Systemic Lupus Erythematosus.

4. Evaluate the effect of applying the self-management guidelines on awareness of patients with Systemic Lupus Erythematosus.

5. Evaluate the effect of applying the self-management guidelines on health outcomes regarding fatigue and pain among patients with Systemic Lupus Erythematosus.

6. Evaluate the effect of applying the self-management guidelines on selfefficacy of patients with Systemic Lupus Erythematosus. 


\section{MATERIAL AND METHODS:}

(I)- Technical Design: includes; research design, setting, subjects, and tools for data collection.

\section{Research Design:}

A quasi-experimental study design was utilized to accomplish the aim of this study.

\section{Setting:}

The study was conducted at the medical inpatients departments and medical outpatient's clinics at Mansoura University Hospital.

\section{Subjects:}

A convenient sample of all available patients admitted to the medical inpatients departments and medical outpatient's clinics at Mansoura University Hospital within 6 months which reached to 65 patients from September 2015 to February 2016 and full filling the following criteria.

Inclusion criteria: Adult patients from both sexes, with different educational levels. Exclusion criteria: Patients with health complications as renal failure, stroke, paralysis, cognitive dysfunction and health team workers.

\section{Tools of data collection:}

\section{Four tools will be used in the current study:}

Tool (1): Health assessment Questionnaire (HAQ): It's a self-administered questionnaire to the patients with Systemic Lupus Erythematosus, to assess the health status of the patients. It's developed by Fries (1978), and recently updated and adapted by Przegl \& Stanford (2008), and Cerner Multum (2011), and modified by researcher, it includes the following:

Part 1: Demographic data of the patient such as (age, sex, marital status, occupation, smoking, treatment cost, medical history and relative degree of family).

Part 2: Disability index to assess dressing\& grooming, arising, eating, walking, hygiene and activities.

Part 3: Drug side effects (toxicity) to assess prescribed medication and any arising problems during the past six months. It was translated from English into Arabic and retranslated was done. 


\section{Scoring system}

Scoring of the part 1 and part 3: Patients answers were tabulated in percentage and frequency values.

\section{Scoring conventions for the disability index:}

The patient response for each statement with 4 answers as follow: without any difficult $=0$, with some difficulty $=1$, with much difficulty $=2$ and unable to do $=3$. The score is calculated by multiplying the highest score (3) by the number of questions (20) to yield the final composite score (60 grades) and then graded as following: $\geq 50 \%$ ( = 30grades $)$ disabled patient, and $<50 \%$ considered able patient.

Tool (2): - Health Outcomes Questionnaire (HOQ): It is a self-administered scale and used to evaluate the impact of fatigue on patients with Systemic Lupus Erythematosus It's composed of 9 statements related to SLE and also to assess severity of pain for SLE patients. It's adopted from Krupp et al., (1989) \& Myrthe et al., (2011). It was translated from English into Arabic and retranslated was done.

\section{Scoring system}

\section{Scoring conventions for the fatigue scale:}

The patient response for each statement was graded from (1 to 3) as follow: $1=$ disagree, $2=$ to some extent and $3=$ agree.

The scoring was done by adding up all the answers which are graded as follows: the total score of 16 or above indicates that a person was suffering from fatigue-related disease, and a score that is lower than 16 shows that health normal.

\section{Scoring conventions for the pain scale:}

The patient response graded as follow: $0=$ no pain, $1-3=$ mild pain, $4-6=$ moderate pain and $7-10=$ sever pain.

- Scores less than $51(<60 \%)$ are considered as unsatisfactory.

- From 51-68 (60\%-80\%) are considered as satisfactory.

- From $68-85(>80 \%)$ are considered as good.

Tool (3): Self-Efficacy Scale (SES): It is a self-administered scale to the patients with SLE, it is used to assess the general Sense of perceived self-efficacy to predict coping\& adaptation after experiencing all kinds of stressful life events; It is adopted from Jerusalem and Schwarzer (1995). It's composed of 10 statements related to SLE. It was translated from English into Arabic and retranslated was done.

\section{Scoring system:}


The patient response for each statement was made on 4-point scale as following: $1=$ not at all true, $2=$ hardly true, $3=$ moderate true and $4=$ exactly true. Sum up the responses to all 10 items to yield the final composite score with range from 10 to 40, and then categorized as follow: less than 20 to $20=$ low self-efficacy and more than $20=$ high self-efficacy.

Tool (4): Lupus Awareness's Quiz (LAQ): It is a self-administered questions used to assess the knowledge level of patients with SLE; it's adopted from Belotti (2003). It is include 20 multiple choice questions related to SLE. It was translated from English into Arabic and retranslated was done.

\section{Scoring system}

The total score of Lupus Awareness was 20 marks. Each correct answer was given one mark and incorrect answer was given zero. It was categorized as follows: $\geq$ $60 \%$ (=12 marks) consider aware and $<60 \%$ consirde not aware.

\section{Suggested self-management guidelines regarding to Systemic Lupus}

Erythematosus: It was designed by the researcher in a simple Arabic language in the form of booklet after intensive reviewing of the related literature; and then reviewed by a jury of medical and nursing expertise.

\section{(II)- Operational Design:}

This phase includes a preparatory phase, content validity and reliability, pilot study, and field work:

\section{Preparatory phase:}

A review of the current available literature and theoretical knowledge was done using books, articles, periodicals, magazines, and internet search to develop the tools for data collection.

\section{Content validity and reliability:}

\section{1) Test validity}

An opinionire sheet was developed by the researcher to assess face and content validity of the developed tools through a group of seven experts who composed of (two professors, two assistant professors and one lecture of medicalsurgical nursing) from the Faculty of Nursing, Mansoura University; and two experts from rheumatology physicians at Faculty of Medicine-Mansoura University. The experts reviewed the tools for clarify, relevance, comprehensiveness, translation and 
simplicity; then based on opinion of jury minor modifications were done and then the final form were developed.

\section{2) Test reliability}

Testing the reliability of the proposed tools was done by Cronbach's alpha test was used to measure the internal consistency of 4 tools used in the current study. The reliability score of the tool above is $(0.715)$.

\section{Pilot study:}

A pilot study was applied on $10 \%$ of patients within the selected criteria to test the applicability of the tools, and estimate the time needed for each sheet to be filled in. Then those who participated in the pilot study were excluded from the main study sample. Modifications of tools were done accordingly.

\section{Data collection procedure:}

The actual Data collection procedure of this study started at the beginning of September, 2015 and had been completed by February, 2016. The researcher was available at medical department inpatients and medical clinics outpatients at Mansoura University Hospital 3 days/week. The collection data is done through three phases:

Phase 1: Assessment data collected by the researcher after distribution of the tools for each patient individually, collection of data was begun by the health assessment questionnaire, it completed by the patient within (20-30 min), Lupus Awareness's Quiz was given to the patient to be answered within about (15-20 min), self-efficacy and health outcome(fatigue \& pain) scales will be then distributed at the end to be completed by patient within about (10-15 min) for each scale.

Phase 2: Implementation of three sessions for each patient was established for explanation of the self-management's guideline, each session will be completed within (45min-1 hour).

Session (1): was composed of filling the tools by the patient, with the help of the researcher for any explanation after that a general identification for the selfmanagement guideline booklet was identified. The patient allowed taking booklet to starting reading at home and underlining any clarifications about items of self-management. 
Session (2): the researcher starting to discuss parts (No 1, 2 and 3) included in the booklet in details with the patients

Session (3): the researcher starting to discuss the last part included in the booklet in details with the patients, and then tools of data collection distributed again to filled by the patients.

Phase 3: At last evaluation the same tools included (health assessment questionnaire, erythematosus knowledge sheet, self-efficacy and health outcome (fatigue \& pain) scales) were distributed again for each patient to be answered to evaluate the effect of self-management guideline implementation.

\section{(III)- Ethical Consideration:}

An official permission will be taken from hospital administrators, to enhance their cooperation. The purpose and nature of the study will be explained to participated patients after receiving their approval to participate in the study. Ensuring anonymity and confidentiality of the information collected. Patients were allowed to choose to participate or not and they were informed that they have the right to withdraw from the study at any time without given any reason.

\section{(IV)- Statistical Design:}

All collected data were organized, categorized, tabulated, entered, and analyzed by using the statistical package for social sciences (SPSS), software program, version 17, and (excel 2007) to evaluate the study subjects throughout the study phases(pre \& post) and to evaluate the differences between the groups under study as regards the various parameter. Statistical analysis include; percentage (\%), the arithmetic mean $(X)$, standard deviation (SD), "t" test, Chi-square $\left(X^{2}\right)$, P value, alpha Cronbach and coefficient correlation ( $r$ ) to detect the relations between the variable.

\section{Significance of results was as the following:}

- When P > 0.05 there was no statistically significant differences.

- When $\mathrm{P} \leq 0.05$ there was statistically significant differences.

- When $\mathrm{P}<0.001$ there was highly statistically significant differences. 


\section{RESULTS:}

Table (1) shows that mean age of studied patients were $32.33 \pm 10.03$, and $92.3 \%$ of them were female. Also it revealed that about two third of the patients $(70.8 \%)$ were married. Regarding the educational level, $7.7 \%$ of the patients were illiterate and less than one third of the patients $(30.8 \%)$ were highly educated. Concerning to working, about two thirds of the patients $(72.3 \%)$ were not working (house wives, student or retired). As regards treatment fees paid, more than two fifth of patients $(41.5 \%)$ were treated at state expense and only $(6.2 \%)$ were treated for private.

Table (2) shows that the highest needed devices used by patients and presents less than one half of patients (46.2\%) were trusses (bandages.etc.), while about one third of them $(32.3 \%)$ uses the cane pre implantation of the guidelines and became more than one quarter $(26.2 \%)$ post implementing the guideline. Also this table shows no statistically significant difference regarding assistive devices needed among patients under study.

Table (3) shows that patient needs help from another person as it was dressing and grooming followed by arising, walking and eating. Also this table shows statistically significant difference regarding the activities of disability index (eating, and walking) with $(\mathrm{P}=0.042$ and 0.047$)$ respectively.

Table (4) shows that all of the patients (100\%) using toilet seat and more than three quarter of patients $(75.4 \%)$ use bath tub seat, while minority of patients $(4.6 \%)$ using bathtub bar pre-implementing of self-management guidelines. Also this table shows no statistically significant difference regarding assistive devices needed among studied patients.

Table (5) as it shown it was errands and chores followed by hygiene, griping and reach. Also this table shows no statistically significant difference regarding the activities of disability index (hygiene, gripping and opening things, reach and errands and chores $)$ with $(\mathrm{P}=0.714,0.291,0.730$ and 0.314$)$ respectively.

Table (6) shows that more than three fifth (64.6\%) of the patients under the study complains of moderate pain and less than one fifth (16.9\%) of them complain of severe pain in pre implementation of self-management guidelines, while in post implementation of self-management guidelines no patients have severe pain and (12.3 $\%$ ) of patients under study were have no pain. Also this table shows high statistically significant difference regarding severe pain with $(\mathrm{P}=<0.001)$.

Table (7) shows that majority of patients (93.8\%) included in the study postimplementation of the self-management guidelines were able regarding score of disability index. Also this table shows statistically significant difference regarding disability index with $(\mathrm{P}=0.033)$. 
Table (8) shows that more than three quarter of patients (78.5\%) included in the study post-implementation of the self-management guidelines were normally health related to the disease fatigability. Also this table shows statistically significant difference regarding fatigue severity with $(\mathrm{P}=0.014)$.

Table (1): Demographic characteristics of studied patients with SLE (No=65):

\begin{tabular}{|c|c|c|}
\hline Items & $\overline{\mathbf{N}}$ & $\%$ \\
\hline \multicolumn{3}{|l|}{ Age } \\
\hline $18-<25$ & 19 & 29.2 \\
\hline $25-<45$ & 38 & 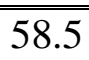 \\
\hline 45 or more & 8 & 12.3 \\
\hline Range & \multicolumn{2}{|c|}{$18-59$} \\
\hline Mean \pm SD & \multicolumn{2}{|c|}{$32.33 \pm 10.03$} \\
\hline \multicolumn{3}{|l|}{ Gender } \\
\hline Female & 60 & 992.3 \\
\hline Male & 5 & 7.7 \\
\hline \multicolumn{3}{|l|}{ Marital status } \\
\hline Married & 46 & 70.8 \\
\hline Single & 15 & 23.1 \\
\hline "Widow & 3 & $\begin{array}{c}4.6 \\
\end{array}$ \\
\hline Divorced & $\overline{11}$ & 1.5 \\
\hline \multicolumn{3}{|l|}{ Education } \\
\hline Illiterate & 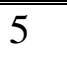 & 7.7 \\
\hline Read/write & 16 & 24.6 \\
\hline Moderate & 24 & 36.9 \\
\hline High & 20 & 30.8 \\
\hline \multicolumn{3}{|l|}{ Working } \\
\hline Working & 18 & 27.7 \\
\hline Not working & 47 & 72.3 \\
\hline \multicolumn{3}{|l|}{ Treatment fees } \\
\hline "Health insurance & 20 & 30.8 \\
\hline Free & 14 & 21.5 \\
\hline At state expense & 27 & 41.5 \\
\hline Private & $\overline{44}$ & 6.2 \\
\hline
\end{tabular}


Table (2): Using assistive devices needed among studied patients with SLE regarding dressing, eating, arising and walking pre and post implementing of self-management guidelines $(\mathrm{No}=65)$ :

\begin{tabular}{||l||l|l||l||l|l|l||}
\hline \multirow{2}{*}{ Items } & \multicolumn{2}{l||}{ Pre } & \multicolumn{2}{l||}{ Post } & \multicolumn{2}{l|}{ Chi-square } \\
\cline { 2 - 7 } & \hline $\mathbf{N}$ & $\%$ & $\mathbf{N}$ & $\%$ & $\mathbf{X}^{2}$ & $\begin{array}{l}\text { P- } \\
\text { value }\end{array}$ \\
\hline Cane & 21 & 32.3 & 17 & 26.2 & 0.595 & 0.441 \\
\hline \hline Walker & 5 & 7.7 & 2 & 3.1 & 1.359 & 0.244 \\
\hline Wheelchair & 2 & 3.1 & 2 & 3.1 & 0.475 & 0.491 \\
\hline Trusses (bandages.etc) & 30 & 46.2 & 29 & 44.6 & 0.031 & 0.860 \\
\hline Devices used for dressing & 4 & 6.2 & 7 & 10.8 & 0.894 & 0.344 \\
\hline Special or built up chair & 2 & 3.1 & 0 & 0.0 & 2.031 & 0.154 \\
\hline Built up or special utensils & 2 & 3.1 & 2 & 3.1 & 0.000 & 1.000 \\
\hline
\end{tabular}

Non sig. $>0.05$ Sig. $<0.05^{\star}$ Highly sig. $<0.001^{*}$

Table (3): Activities of disability index (dressing, eating, arising and walking) among studied patients with SLE pre and post implementation of self-management guidelines (No=65):

\begin{tabular}{|l|l||l|l|l||l|l|}
\hline \multirow{2}{*}{ Items } & \multicolumn{2}{|l|}{ Pre } & \multicolumn{2}{l|}{ Post } & \multicolumn{2}{l|}{ Chi-square } \\
\cline { 2 - 7 } & N & $\%$ & N & $\%$ & $X^{2}$ & P-value \\
\hline Dressing and Grooming & 43 & 66.2 & 42 & 64.6 & 0.034 & 0.854 \\
\hline Arising & 34 & 52.3 & 31 & 47.7 & 0.277 & 0.599 \\
\hline \hline Eating & 4 & 6.2 & 0 & 0.0 & 4.127 & $0.042^{*}$ \\
\hline \hline Walking & 30 & 46.2 & 19 & 29.2 & 3.963 & $0.047 *$ \\
\hline
\end{tabular}

Non sig. $>0.05$ Sig. $<0.05^{\star}$ Highly sig. $<0.001^{*}$ 
Table (4): Assistive devices needed for studied patients with SLE regarding hygiene, reach, gripping and errands pre and post-implementation of self-management guidelines $(\mathrm{No}=65)$ :

\begin{tabular}{|l||l|l|l|l|l|l|}
\hline \multirow{2}{*}{ Items } & \multicolumn{2}{l|}{ Pre } & \multicolumn{2}{l|}{ Post } & \multicolumn{2}{l|}{ Chi-square } \\
\cline { 2 - 7 } & $\mathbf{N}$ & $\%$ & $\mathbf{N}$ & $\%$ & $\mathbf{X}^{2}$ & P-value \\
\hline \hline Raised toilet seat & 65 & 100.0 & 63 & 96.9 & & \\
\hline \hline Bathtub seat & 49 & 75.4 & 43 & 66.2 & 1.339 & 0.247 \\
\hline $\begin{array}{l}\text { Long-handled } \\
\text { appliances } \\
\text { bathroom }\end{array}$ & 23 & 35.4 & 19 & 29.2 & 0.563 & 0.453 \\
\hline $\begin{array}{l}\text { Long-handled } \\
\text { appliances for reach }\end{array}$ & 11 & 16.9 & 8 & 12.3 & 0.555 & 0.456 \\
\hline \hline \begin{tabular}{l} 
Jar opener \\
\hline \hline
\end{tabular} & 35 & 53.8 & 31 & 47.7 & 0.492 & 0.483 \\
\hline Bathtub bar & 3 & 4.6 & 0 & 0.0 & 3.071 & 0.080 \\
\hline
\end{tabular}

\section{Non sig. $>0.05$ Sig. $<0.05^{\star}$ Highly sig. $<0.001^{*}$}

Table (5): Activities of disability index (hygiene, gripping and opening things, reach and errands and chores) among studied patients with SLE pre and post implementation of self-management guidelines $(\mathrm{No}=65)$ :

\begin{tabular}{|l|l|l||l|l|l|l||}
\hline \multicolumn{2}{|l|}{} & \multicolumn{2}{l||}{ Pre } & \multicolumn{2}{l|}{ Post } & \multicolumn{2}{l|}{ Chi-square } \\
\cline { 2 - 7 } & \multicolumn{1}{|l|}{ Items } & $\%$ & $\mathbf{N}$ & $\%$ & $\mathbf{X}^{2}$ & $\begin{array}{l}\text { P- } \\
\text { value }\end{array}$ \\
\hline \hline Hygiene & 43 & 66.2 & 41 & 63.1 & 0.135 & 0.714 \\
\hline $\begin{array}{l}\text { Gripping and opening } \\
\text { things }\end{array}$ & 33 & 50.8 & 27 & 41.5 & 1.114 & 0.291 \\
\hline \hline Reach & 5 & 7.7 & 4 & 6.2 & 0.119 & 0.730 \\
\hline Errands and chores & 51 & 78.5 & 46 & 70.8 & 1.015 & 0.314 \\
\hline
\end{tabular}


Table (6): Severity of pain among studied patients with SLE pre and post implementation of self-management guidelines $(\mathrm{No}=65)$ :

\begin{tabular}{|l|l|l|l|l|l|l|}
\hline \multirow{2}{*}{ Degree of pain } & \multicolumn{2}{l|}{ Pre } & \multicolumn{2}{l|}{ Post } & \multicolumn{2}{l|}{ Chi-square } \\
\cline { 2 - 7 } & \multicolumn{1}{l}{$\mathrm{N}$} & $\%$ & $\mathrm{~N}$ & $\%$ & $\mathrm{X}^{2}$ & P-value \\
\hline No pain & 0 & 0.0 & 8 & 12.3 & 8.525 & $0.004^{*}$ \\
\hline Mild & 12 & 18.5 & 8 & 12.3 & 0.945 & 0.331 \\
\hline Moderate & 42 & 64.6 & 49 & 75.4 & 1.795 & 0.180 \\
\hline \hline Sever & 11 & 16.9 & 0 & 0.0 & 12.017 & $<0.001^{* *}$ \\
\hline \hline Total & 65 & 100.0 & 65 & 100.0 & 20.338 & $<0.001^{* *}$ \\
\hline
\end{tabular}

Non sig. $>0.05$ Sig. $<0.05^{*}$ Highly sig. $<0.001^{*}$

Table (7): Relation between total of disability index of studied patients with SLE pre and post-implementation of the self-management guidelines $(\mathrm{No}=65)$ :

\begin{tabular}{|l|l||l|l||l||l|l||}
\hline \multirow{2}{*}{ Disability } & \multicolumn{2}{|l|}{ Pre } & \multicolumn{2}{|l||}{ Post } & \multicolumn{2}{l||}{ Chi-square } \\
\cline { 2 - 5 } & $\mathrm{N}$ & $\%$ & $\mathrm{~N}$ & $\%$ & $\mathrm{X}^{2}$ & P-value \\
\hline \hline Able & 53 & 81.5 & 61 & 93.8 & \multirow{2}{*}{4.561} & \multirow{2}{*}{$0.033^{*}$} \\
\hline \hline Disable & 12 & 18.5 & 4 & 6.2 & & \\
\hline \hline
\end{tabular}

Non sig. $>0.05$ Sig. $<0.05^{\star}$ Highly sig. $<0.001^{*}$

Table (8): Relation between total of fatigue severity among studied patients with SLE pre and post-implementation of the self-management guidelines $(\mathrm{No}=65)$ :

\begin{tabular}{|l|l|l||l|l|l|l|}
\hline \multirow{2}{*}{ Fatigue } & \multicolumn{2}{|l||l|l|}{ Pre } & \multicolumn{2}{l|}{ Post } & \multicolumn{2}{l|}{ Chi-square } \\
\cline { 2 - 6 } & $\mathbf{N}$ & $\%$ & N & $\%$ & $X^{2}$ & P-value \\
\hline Normal health & 38 & 58.5 & 51 & 78.5 & \multirow{2}{*}{6.021} & \multirow{2}{*}{$0.014^{*}$} \\
\hline \hline Fatigue related disease & 27 & 41.5 & 14 & 21.5 & & \\
\hline
\end{tabular}

Non sig. $>0.05$ Sig. $<0.05^{*}$ Highly sig. $<0.001^{*}$

\section{DISCUSSION}

Demographic characteristics of studied patients revealed that; in relation to age more than half of their patients age, was falls between 25 and $<45$ years. This in agreement with Lupus Foundation of American(2012) and Sestak, Furnrohr, Harley, Merrill \& Namjou(2011) who stated that; the most common age for SLE is between 15-45 years which called the bearing age which means that in this period 
hormones influencing vulnerability to this disease. Also regards gender the current study showed that majority of the study subjects were females. These go in the same line with Tsokos (2012) who stated that SLE affecting women nine times more than men. This explained by Sanz (2010) who mentioned that; the biggest difference in the occurrence of lupus between men and women may be because women experience highest exposure to estrogen hormone, it is also possible that the male hormone, androgen, may have a protective function in lupus.

Regarding marital status, the present study finding showed that, about two third of the patients were married, these findings were in agreement with Mendoza $\&$ Carrasco (2011) who reported that approximately the same results in their study on patients with SLE. This might due to that the incidence of the disease is usually occurring at the bearing age.

Concerning educational level of studied sample, the result of the current study showed that about quarter of the patients were able to read and write and nearly two fifth of them have moderate educational level. This is in accordance with results of Ritterhouse, Crowe and Niewold (2012) that studied the effect of self-management guidelines on patients with diabetes mellitus and stated that exclusion of illiterate's patients is much suitable to help those patients in reading guidelines and instructions by themselves which implies much better effect to understand especially at home.

In relation to patients working status, the present study findings showed that about two thirds of the patients were not working. These findings were correspondent with Hakim, Furnrohr \& Amann (2011) who reported that; more than half of these study groups were unemployed. This finding might be related to gender or complications occurred.

As regards the treatment fees, its revealed that more than two fifth of patients were treated in Mansoura University hospital at state expense and less than one third of them were treated by health insurance. These findings were in the same line with De Groot (2013) who stated that; patients with SLE in his own research were treated mostly at the national hospital for free or on the account of their health insurance. This might due to that mostly SLE attacking female who have low economical source. 
In relation to scoring of disability index pre \& post implementation of selfmanagement guideline, the study revealed that more than four fifth of patients pre implementation of self-management guide line able to doing some activities without any difficulties with 3 disability index, Turn faucets, Lift a foil cup or glass to mouth and Open jars respectively. Which increased to majority post implementation of selfmanagement guidelines able without any difficult with 3 disability index, Lift a foil cup or glass to your mouth, Open jars and Turn faucets. These findings were agreement with Koehler (2011), Wang \& Osmond (2010) who find that; the majority of patients with SLE are disabling to perform the usual daily activities. This could be referred to joint and/or muscle pain during the course of the illness. Therefore more than 90 percent of people with SLE have experience disability problems.

In relation to the fatigue severity among studied patients, it was revealed that more than half of patients pre implementation of self-management guidelines had agree that fatigue interferes with three disability symptoms, exercise, physical functioning, carrying out certain duties and responsibility and easy fatigued, which decreased post-implementation of self-management guidelines to be more than one third had agree that fatigue interferes with 3 disability symptoms, exercise, easy fatigue, physical functioning and carrying out certain duties and responsibility. This result in the same line with Lupus Foundation of America (2011) who stated that; the effect of the guidelines when followed by the patients as it could decrease the fatigability among them. This result might due to the need of these patients to decrease their fatigue to properly acts in their lives.

As regards to the health outcomes as pain sensation in the current study, it was found that all of the patients complain of pain pre-implementation of selfmanagement guidelines which slightly decreased post- implementation of selfmanagement guidelines. This results consonant with Godron \& Smythe (2011) who reported that; more than three quarters of patients with SLE complain of moderate to severe pain occurring from the muscle and bone aches regarding the degenerative effects of lupus on the body systems. This might explain the feeling of generalized pain resulted from the multiple inflammations of the blood vessels of various body organs. 
According to the over items of self-management, the current study showed highly statistical significance difference regarding level of awareness and health outcome regarding pain severity, also showed statistically significance regarding disability index, health outcome regarding fatigue severity and self-efficacy among the patients under the study regarding implementing of self-management guidelines. This result is correspondent with Nicol $\&$ Warier (2011) who was found the same results after application of self-management course on patients with arthritis in SLE.

Regarding the overall level of disability among the patients with SLE, the current study showed statistically significance difference among the levels of disability pre/post implementation of self-management guidelines. This is correspondent with Watson (2011) \& Giverson (2011) who was found the same result after application self-management course on patients with arthritis in SLE. These ensure that offering the self-management guidelines to decrease fatigue could be helping patients to act as normal persons. On the other hand these findings were in disagreement with Koehler (2011) and Wang \& Osmond (2010) who found the majority of patients with SLE post education program are disabling to perform the usual daily activities. This disability resulted from joint and/or muscle pain during the course of their illness.

\section{CONCLUSION:}

\section{Based on the findings of the present study, it can be concluded that:}

The systemic Lupus Erythematosus self-management guidelines had positive effects on the patients in reducing disability, fatigue severity, pain severity, improving self-efficacy and patient's awareness. More than two third of patients included in the study were had high self-efficacy and majority of patients included in the study had satisfactory awareness level. There were high statistically significant difference regarding severe pain, generalized health status and level of awareness $(\mathrm{P}<0.001)$ post implementation of self-management guidelines. Moreover highly statistically significant differences between patients fatigue severity and their socio-demographic characteristics regarding to education and smoking.

\section{RECOMMENDATIONS:}

\section{Based on the findings of this study, the following can be recommended:}

1. Design and implement self-management programs for patients with SLE in hospitals. 
2. An Arabic guided images booklet and procures about SLE should be distributed for each newly patient diagnosed with SLE.

3. Further researches about self-management of patients with SLE are highly recommended to reach the peak level of health satisfaction among those patients.

\section{REFERENCES:}

Bellotti M. (2003): Systemic Lupus Erythematosus Quizes. Lancet. Feb 17; 369 (9561): 587-96.

Cerner Multum W., \& Wolters T. (2011): Novel evidence-based systemic lupus erythematosus responder index. Arthritis Rheum. Sep 15; 61 (9): 1143-51.

De Groot F. (2013): Baseline characteristics of a multiethnic lupus cohort: PROFILE. Lupus. 11:95-101.

DeCastro L., Morales W., \& Wagner W. (2011): Clinical Manifestations of Systemic Lupus Erythematosus. In: Harris ED, et al, eds. Kelly's Textbook of rheumatology. $7^{\text {th }}$ ed. Philadelphia, Pa: WB Saunders; p.p. 1201-24.

Fries JF. (1978): Quality of life and Pharmacoleconomics in Clinical Trials, $2^{\text {nd }}$ ed, The Health Assessment Questionnaire- Status and Review. Philadelphia: Lippincott-Raven Pub, p227-237.

Giverson U. (2011): EULAR recommendations for the management of systemic lupus erythematosus. Report of a tasked of the EULAR Standing Committee for International Clinical Studies Including Therapeutics. Ann Reum; 67(10):195205.

Gordon K., \& Smythe R. (2011): Systemic lupus erythematosus: clinical and immunologic patterns of disease expression in cohort of 1,000 patients, $6^{\text {th }} \mathrm{ed}$, Philadelphia, Pa: WB Saunders, p.p. 458-489.

Hakim L., Furnrohr R \& Amann A. (2011): Under treatment of disease Activity in Systemic Lupus Erythematosus Patients with End stage Renal Failure is Associated with Increased All-cause Mortality. J Rheumatol. Nov; 38(11):2382-9. 
Jerusalem, K., \& Schwarzer, T. (1995): Self efficacy. In M. Gerrard \& K. D McCaul (Eds), health behavior constructs: Theory, measurement and research.

National Cancer Instituten. Available at: http://dccps.cancer.gov/brp/constructs/selfefficacy/index.html. Accessed in 11 June 2014.

Koehler F. (2011): Recommendations for adults patients with autoimmune inflammatory rheumatic disease, $2^{\text {nd }}$ ed, Mosby. Boston, Toronto. London, pp. 61-70.

Krupp L., LaRocca N., Muir-Nash J., \& Steinberg A. (1989): The fatigue severity scale(FSS), Application to patients with multiple sclerosis and systemic lupus erythematosus. Arch Neurol 46 (10): 1121-1123. PubMed Abstract/Publisher full Text.

Long C. (2013): Disease-specific quality indicators, guidelines, and outcome measures in systemic lupus erythematosus (SLE). Clin Exp Rheumatol. NovDec; 25(6 Suppl 47): 107-13.

Lupus Foundation of America. (2011): What are the risks for developing lupus? URL Available at: http://www.lupus.org/webmodules/webarticlesnet/tem Plates/new_learnunderstanding.aspex? Articleid=2237 \& zoneid=523. Accessed November 22, 2012.

Lupus Foundation of America. (2012): Guidelines for screening, treatment, and management of lupus nephritis. Arthritis Care Res (Hoboken).64(6): 797-808.

Mendoza T., \& Carrasco A. (2011): The lupus band test in systemic lupus erythematosus, $2^{\text {nd }}$ ed, Tronto, Saunders Comp.,p.p.100-20.

Myrthe J., Ottenhoff T., Dick U., \& Rob de Jong. (2011): Prognosis, mortality and morbidity in systemic lupus erythematosus, $7^{\text {th }}$ ed. Philadelphia: Lippincott Williams \& Wilkins; p.p. 1333-53.

Nicol T., \& Warier M. (2011): Glucocorticoid in systemic lupus erythematosus. Clin Exp Rheumatol. Sep-oct 2011; 29(5 Suppl 68):S126-9. 
Przegl Lek. (2008): Socio-economic evaluation among patients with chronic illness, Philadelphia: Lippincott Williams \& Wilkins; p.p. 838-850.

Rahman A \& Isenberg D. (2012): Systemic lupus erythematosus. $N$

Eng J Med; 358: 929-939.

Ritterhouse L., Crowe S., \& Niewold TB. (2011): Vitamin D deficiency is associated with an increased autoimmune response in health individuals and in patients with systemic lupus erythematosus. Ann Rheum Dis. Sep 2011; 70(9): 1569-74.

Sanz Y. (2010): Experimental reproduction of skin lesions in lupus erythematosus by UVA and UVB radiation. J Am Acad Dermatol. Feb 2010; 22(2Pt 1):181-7.

Sestak A., Furnrohr B., Harley J., \& Namjou B. (2011): The genetics of systemic lupus erythematosus_and implications for trargeted therapy. Ann Rheum Dis. Mar 2011; 70 Suppl 1: i37-43.

Stanford Health Assessment Questionnaier. (2008): A review of its history, issues, progress \& documentation. J Rheumatol, 30(1): 167-8.

Tsokos G. (2011): Systemic lupus erythematosus. N Engl J Med. Dec 2011; 365(22): 2110-21.

Wang R., \& Osmond W. (2010): European League against Rheumatism recommendations for monitoring patients with systemic lupus erythematosus in clinical practice and in observational studies. $6^{\text {th }}$ ed, Mosby; Louis Street, New York, pp. 322-330.

Watson R. (2011): Morbidity and mortality in systemic lupus erythematosus during a 10- year period. A comparison of early and late manifestations in a cohort of 1000 patients. Medicine (Baltimore); 82:299-308. 


\section{أثرإششادات الرعاية الأتية على المخرجات الصحية لمرضى الأببة الحمراء}

أ.د / لبيبة عبد القادر محمد ${ }^{1}$ ـ. أ. د/ عبد الرازق عبد اللطيف معاطى 2 ـ أ. م. د/ إيمان صالح شاهين 3 ـ أ.

\section{م. د/ أمل بكر أبو العطا4 ـ شيماء السيد مسعد محمد5}

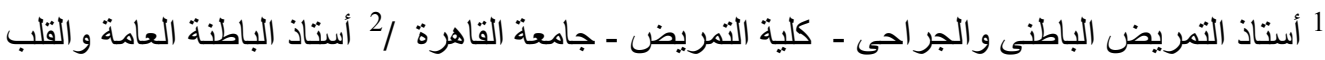

و الأو عية الدموية ـ كلبة الطب - جامعة المنصورة / 3 أستاذ مساعد التمريض الباطني و الجر احيـ كلية

التمريض- جامعة بورسعيد/ 4 أستاذ مساعد التمريض الباطني و الجر احي- كلية التمريض- جامعة بورسعيد / 5

أخصائي تمريض - جامعة المنصورة.

\section{الـخـلاصــة}

الذئبة الحمر اء الجهازية هو مرض يصيب الجهاز المناعى ويعتبر مرض من الأمر اض الروماتيزمية

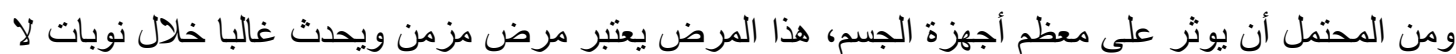

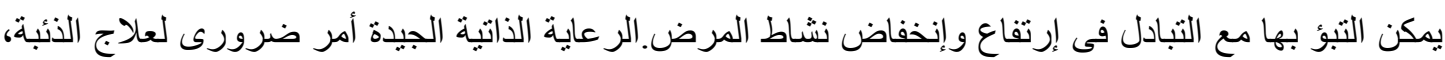

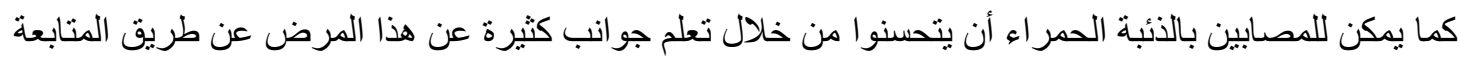
مع مقدمى الرعاية لهم ـ كان الهدف من هذه الدراسة تقييم أثرإرشادات الرعاية الذاتية على الوعى المعرفى ، الحالة الصحية و الكفاءة الذاتية لمرضى الذئبة الحمر اء فى مستشفى الجامعة بالمنصورة. تم إستخدام دراسة شبه تجريبة فى البحث. تم تنفيذ هذه الدر اسة في عيادات الباطنة و أقسام الباطنة بمستشفى الجامعة بالمنصورة، شملت عينة البحث جميع المرضى المتاحين من عبادات و أقسام الباطنة بمستشفى الجامعة بالمنصورة خلال 6 شهور والتى وصلت إلى 65 مريض إبتدا من سبتمبر 2015 إلى فبراير 2016. وتتثمل أدوات جمع البيانات 1 ) إستبيان لتقييم الصحة ، 2) إستبيان لتقييم المخرجات الصحية ويحتوى على مقياس شدة التعب وشدة الألم ، لمرضى الذئبة الحمر اء. وقد أوضحت الدراسة أن إرشادات الرعاية الذاتية لمرضى الذئبة الحمراء لها آثار

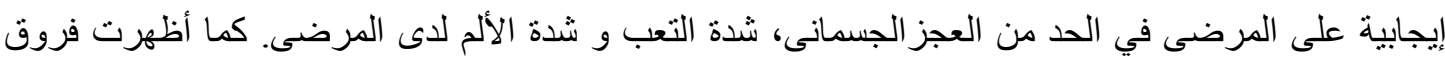
ذات دلالة إحصائية عالية تجاه الألم الثديد، الحالة الصحية العامة و مستوى الوعي المعرفى لدى المرضى . علاوة على ذلك وجد أن هناك علاقة ذات دلالة إحصائية بين شدة التعب للمرضى والخصائص الإجتماعية و الديمو غر افية المتعلقة بالتعليم والتدخين. 